\title{
Seafloor spreading magnetic anomalies south off Sri Lanka
}

\author{
M. Desa*, M. V. Ramana, T. Ramprasad \\ National Institute of Oceanography, Dona Paula, Goa 403 004, India
}

\begin{abstract}
Results obtained from compilation and reinterpretation of about 21,200 line $\mathrm{km}$ of bathymetry, magnetic and satellite gravity data between $10^{\circ} \mathrm{S}$ to $10^{\circ} \mathrm{N}$ latitudes and 75 to $90^{\circ} \mathrm{E}$ longitudes south off Sri Lanka are presented here. Magnetic data and the synthetic seafloor spreading model reveal the presence of Mesozoic anomaly sequence M11 through M0 south of Sri Lanka. The oldest magnetic anomaly M11 (134Ma) occurs between 110 and $140 \mathrm{~km}$ away from the Sri Lankan coast. The seafloor created during the Early Cretaceous is estimated to have evolved with variable half-spreading rates ranging from 5.5 to $1.53 \mathrm{~cm} / \mathrm{yr}$. The trends of the fracture zones inferred from the offsets in the magnetic anomalies have been constrained using the satellite gravity mosaic. The Cretaceous Magnetic Quiet Zone (CMQZ, 121-84 Ma) crust between the isochrons $\mathrm{MO}$ and $\mathrm{A} 34$ has an unequal width and widens from about $170 \mathrm{~km}$ in the west $\left(80^{\circ} \mathrm{E}\right.$ longitude) to about $500 \mathrm{~km}$ towards east $\left(85^{\circ} \mathrm{E}\right.$ longitude). Plate reconstruction models for $160 \mathrm{Ma}$ (Fit), $134 \mathrm{Ma}$ (M11), $121 \mathrm{Ma}$ (M0) and $84 \mathrm{Ma}$ (A34) are generated under the constraints of newly identified magnetic anomaly isochrons and fracture zones. The mismatch in the A34 reconstruction is attributed to the emplacement of the $\mathrm{Ob}$, Lena and Marion Dufresne seamounts at the spreading ridge axis and/or the frequent ridge jumps in the Middle Cretaceous during the major plate reorganization.
\end{abstract}

Key words: Gondwanaland, Mesozoic magnetic anomalies, Cretaceous Magnetic Quiet Zone, Sri Lanka, tectonic reconstruction and GEOSAT derived gravity data

\footnotetext{
* Corresponding author. Tel.: 91-832-2450326; Fax: 91-832-2450601; E-mail: mdesa@nio.org
} 


\section{Introduction}

The breakup of eastern Gondwanaland and the subsequent rifting and drifting of its continents in space and time are responsible for the creation of the present day configuration of the Indian Ocean. Seafloor spreading occurred in three episodes with two major plate reorganizations (Schlich, 1982; Mckenzie and Sclater, 1971; Norton and Sclater, 1979; Powell et al., 1988; Scotese et al., 1988; Royer et al., 1989). The initial breakup between India and the contiguous Antarctica-Australia continent has been suggested to occur prior to M11 time (134 Ma) (Ramana et al., 1994; 2001). The first major plate reorganization began around $\mathrm{M} 0$ time and the direction of motion of the Indian plate changed from NNW-SSE to N-S. A second episode of seafloor spreading occurred from Late Cretaceous to middle Eocene (84-50 Ma) during which the Indian plate moved rapidly northward. This northward movement was drastically reduced around $\sim 50$ Ma due to the soft collision of Indian plate with the Eurasian plate, which triggered the second major plate reorganization (Powell et al., 1988). During this reorganization, the direction of the Indian plate motion changed from N-S to NE-SW. A third phase of seafloor spreading commenced during the Oligocene ( $\sim 30 \mathrm{Ma})$ in the NE-SW direction and prevails to date.

Several authors (Mckenzie and Sclater, 1971; Norton and Sclater, 1979; Powell et al., 1988; Curray and Munasinghe, 1991; Johnson et al., 1976) proposed different plate reconstruction models and explained the tectonic evolution of the Indian Ocean. The early separation between Australia and Greater India is well documented by the identification of Mesozoic magnetic anomalies in the Perth Basin, west of Australia (Markl, 1974; Larson, 1977; Robb et al., 2005). Further, recent studies by Ramana et al., (1994; 2001) reveal the presence of Mesozoic magnetic anomaly sequence M11 to M0 in the Bay of Bengal and its conjugate, the Enderby Basin, East Antarctica, and the Cretaceous Magnetic Quiet Zone (CMQZ) in the distal Bengal Fan (Ramana et al., 1997a). 
Understanding the crustal configuration off Sri Lanka, a part of the Indian plate, is vital to generate more accurate plate reconstruction models. Hence, an attempt has been made in this paper to interpret the available magnetic and bathymetry data off Sri Lanka retrieved from NGDC and the Data Center of NIO. The GEOSAT/ERS-1 derived gravity data has also been used to infer fracture zones and other structural elements. A synthetic seafloor spreading model has been generated to identify the seafloor spreading magnetic anomalies. The average half-spreading rates and direction of spreading for the identified anomaly sequence are estimated in order to explain the evolutionary history of the crust south off Sri Lanka.

\section{Study area}

The study area lies south off Sri Lanka (Fig. 1) and is bounded by the N-S trending Chagos-Laccadive and Ninetyeast Ridges in the west and east respectively. The NNW-SSE trending Comorin Ridge (Heezen and Tharp, 1964 ) and the southern portion of the subsurface $85^{\circ} \mathrm{E}$ Ridge (Curray et al., 1982) are two important known structural elements present in the study area.

The $85^{\circ} \mathrm{E}$ Ridge trends approximately $\mathrm{N} 10^{\circ} \mathrm{W}$ between 6 and $19^{\circ} \mathrm{N}$ latitudes and occurs approximately parallel to the $85^{\circ} \mathrm{E}$ meridian. The ridge is characterized by positive magnetic (100-400 nT) and negative free-air gravity (-60 mGal) anomalies. Off the southeast coast of Sri Lanka, it manifests into an arcuate shape and appears to abut with the northern extension of the Afanasy Nikitin seamounts. Several workers postulated different theories to explain its origin (e.g., abandoned spreading center, northward continuation of the $86^{\circ} \mathrm{E}$ fracture zone, hotspot trace etc). Based on the characteristic geophysical anomaly signatures (steep gradient negative gravity and positive magnetic anomalies), Ramana et al., (1997b) proposed two alternate processes for its emplacement. The proposed processes are: shearing of the lithosphere caused by (a) stretching and compressional forces associated at the time of major plate reorganization immediately after the evolution of the M0 crust in the Bay of Bengal and/or (b) due to sagging of the lithosphere followed by 
deformation caused by horizontal compressional forces on the passive continental margin as suggested by Shemenda (1992) through a model study of the lithosphere. However, in absence of ground truth data, the hotspot origin of the ridge as proposed by Curray et al., (1982) cannot be ignored.

Several Tertiary magnetic lineations (A34 to A27) and fracture zones are reported in the study area (Schlich, 1982; Mckenzie and Sclater, 1971; Norton and Sclater, 1979; Sclater and Fisher, 1974; Royer et al., 1991). The scientific results of the ODP drill sites 717 to 719 of Leg 116 situated about $800 \mathrm{~km}$ south of Sri Lanka facilitated in understanding the deformation history of the area (Stein et al., 1990). The intraplate deformation, which is seen south of $4^{\circ} \mathrm{N}$ latitude in the study area, consists of long wavelength undulations (100-300 $\mathrm{km})$ and short wavelength reverse faults $(5-10 \mathrm{~km})$ and associated folds (Bull et al., 1992; Krishna et al., 1998).

The study area lies in the distal Bengal Fan where the sediment thickness is less than $3 \mathrm{~km}$ (Curray, 1994). The NNW-SSE trending Comorin Ridge is associated with pronounced positive isostatic gravity and high amplitude short wavelength magnetic anomalies. According to Kahle et al., (1981), this ridge marks a significant structural crustal boundary. The Mannar Basin, which lies between India and Sri Lanka in water depths ranging up to $3000 \mathrm{~m}$ is filled with $6 \mathrm{sec}$ (TWT) thick sediments of late Jurassic to Recent with four distinct sequences and the oldest sequence was deposited during the initial synrift phase of basin development prior to the commencement of seafloor spreading in the Bay of Bengal (Baillie et al., 2002). This implies that the sediments in the Mannar Basin are as old as Early Cretaceous.

\section{Data and Methodology}

About 19,200 line km of magnetic and bathymetry data retrieved from the archives of the National Geophysical Data Center (NGDC), Colorado and 2,000 line $\mathrm{km}$ of magnetic and bathymetry data acquired by NIO under its R\&D programme on board ORV Sagar Kanya have been compiled (Fig. 2) and analyzed in the present study. The GEOSAT derived gravity mosaic (Fig. 3), 
which depicts high-resolution imprints of several tectonic elements and fracture zones has been used to map the structural configuration. The magnetic data off Sri Lanka was studied to infer the nature and age of the crust, and, the rate and direction of seafloor spreading prevailing during the time of its formation.

In the Eastern Gondwanaland reconstruction, India along with Sri Lanka is placed adjacent to East Antarctica. The initial breakup of this landmass during the Early Cretaceous resulted in the creation of the ocean floor between India and its conjugate, the East Antarctica. Since the Bay of Bengal and Enderby Basin are associated with Mesozoic magnetic anomalies, the oceanic crust south off Sri Lanka must have a similar evolutionary history. Therefore, the observed magnetic anomalies were compared with the Mesozoic magnetic anomalies reported elsewhere (e.g. Larson, 1977; Bergh, 1977; Simpson et al., 1979; Rohr and Twigt, 1980; Ramana et al., 1994; 2001).

A synthetic seafloor-spreading model was generated using the magnetic polarity time scale of Gradstein et al., (1994) to confirm the anomaly identifications. The model was generated by assuming uniformly magnetized blocks with an average thickness of $500 \mathrm{~m}$ and a susceptibility of $0.015 \mathrm{cgs}$ units. The magnetic profile V3308 was considered as the key profile, since it is aligned in an approximate direction of the fracture zones inferred from the satellite gravity mosaic. The best-fit model is obtained with the spreading center oriented approximately $\mathrm{N} 70^{\circ} \mathrm{E}$ direction at $60^{\circ} \mathrm{S}$ latitude. All the magnetic profiles in the study area were projected along the $\mathrm{N} 143^{\circ} \mathrm{E}$ direction (orientation of the fracture zones) and compared with the synthetic model (Fig. 4).

\section{Results}

\subsection{Bathymetry}

Depth to the seabed varies from $<500 \mathrm{~m}$ in the shelf region to $>5000 \mathrm{~m}$ in the south of the study area (Fig. 2). The continental shelf of Sri Lanka is narrow $(\sim 30 \mathrm{~km})$ and depicts steep slope beyond the $500 \mathrm{~m}$ isobath. The Comorin Ridge, characterized with positive rugged topography trends linearly in NNWSSE direction between $2-6^{\circ} \mathrm{N}$ latitudes and $77-79^{\circ} \mathrm{E}$ longitudes. The ridge has a 
relief of about $1000 \mathrm{~m}$ from the surrounding bathymetry of $\sim 3500 \mathrm{~m}$. It is characterized by a steep scarp on its eastern side where the seafloor relief drops from 3000 to $4200 \mathrm{~m}$, while the gradient is relatively gentle on the western slope of the ridge. Isolated topographic highs representing the summits of different charted seamounts are seen scattered in the study area. The Afanasy Nikitin seamount chain, $\sim 330 \mathrm{~km}$ long and $200 \mathrm{~km}$ wide is another conspicuous feature south of Sri Lanka. This seamount chain rises to $\sim 1600 \mathrm{~m}$ from the surrounding seafloor of $>4000 \mathrm{~m}$.

\subsection{Magnetics}

The amplitude of the magnetic anomalies varies between $<-500$ and $>120$ $\mathrm{nT}$ in the study area (Fig. 2). The magnetic anomalies are relatively subdued towards the northeast of the study area as compared to those in the southwest due to sediment overburden. In spite of their subdued nature, the magnetic anomalies retain the characteristic signatures of the seafloor spreading magnetic anomaly pattern. The Afanasy Nikitin seamount chain, the Comorin and $85^{\circ} \mathrm{E}$ Ridges and other isolated seamounts are all associated with large amplitude magnetic anomalies (>500 nT).

Seafloor spreading model studies reveal that the observed magnetic anomalies resemble the Mesozoic magnetic anomaly sequence M11 through M0. Though the magnetic anomalies are subdued in nature, the key anomalies such as M8, M4, M2 and M0 have been recognized with a fair degree of confidence based on their typical anomaly signatures. The oldest magnetic anomaly identified is M11, which suggests the initiation of breakup prior to the formation of the anomaly M11 (134 Ma). Further, the model generated for the key profile V3308 indicates that the oceanic crust was evolved with variable spreading rates (Fig. 4). The Early Cretaceous crust appears to have evolved with an average half-spreading rate of about $5.5 \mathrm{~cm} / \mathrm{yr}$ up to isochron M10 (131 Ma). Thereafter, the half-spreading rate decreased marginally $(\sim 5.25 \mathrm{~cm} / \mathrm{yr})$ up to isochron M4 (126.7 Ma). Subsequently, the half-spreading rate gradually decreased to about $1.53 \mathrm{~cm} / \mathrm{yr}$ around M0 time. The middle Cretaceous crust 
(121 to $84 \mathrm{Ma}$ ) has been estimated to evolve with a slow half-spreading rate of $0.6 \mathrm{~cm} / \mathrm{yr}$ along the direction of the profile V3308 (Fig. 4).

All the magnetic profiles in the study area were projected and compared with the synthetic model (Fig. 4). The isochrons M2 and M0 are confidently identified on all the profiles. The profiles circ04, v3308, sk82-01, v3405 and wi343815-a are aligned in NW-SE direction and cover the eastern part of the study area. The profile c2705-b is aligned in an approximate $\mathrm{N} 100^{\circ} \mathrm{E}$ direction. Most of these profiles depict the anomalies M11 through M0 with several offsets. The profiles c2706-a, inmd7mv, ant11mv-a and odp116jr run in an approximately N-S direction south of Sri Lanka. The full sequence of Mesozoic anomalies M11 through M0 could not be identified on these profiles and the identified isochrons are seen offset at several locations. The magnetic data along a few N-S lines such as circ05, c1709-a, lus7aar, sk82-02 and dsdp22gc were also used to constrain our interpretation. The positions of the identified magnetic isochrons are shown in Figure 5.

\subsection{Satellite derived gravity data}

The satellite derived gravity mosaic (Sandwell and Smith, 1997) reveals the presence of a strong gravity minimum zone (Indian Ocean geoidal low) east of the Comorin Ridge and south of Sri Lanka (Fig. 3). . The map also depicts several distinct tectonic elements such as: i) NNW-SSE trending $100 \mathrm{~km}$ wide and $\sim 450 \mathrm{~km}$ long Comorin Ridge southwest of Sri Lanka, ii) N-S trending clusters of broad positive gravity highs east of $82^{\circ} \mathrm{E}$ fracture zone corresponding to Afanasy Nikitin seamount chain, iii) a prominent linear gravity low along $85^{\circ} \mathrm{E}$ longitude, which takes an arcuate shape towards the southeast of Sri Lanka, iv) the positive gravity expressions of the Ninetyeast Ridge towards far east, v) several N-S trending fracture zones south of the equator, and vi) E-W to ENE-WSW trending alternate bands of gravity highs and lows, south of $4^{\circ} \mathrm{N}$ latitude, corresponding to the basement highs and lows caused by intraplate deformation. A $\sim 190 \mathrm{~km}$ long NE-SW trending tectonic feature ('A' on Fig. 3) has been inferred from the satellite derived gravity mosaic in the Gulf of 
Mannar. This linear feature joins two approximately NNE-SSW trending linear gravity lows, one off southern tip of India, and the other sub-parallel to the west coast of Sri Lanka ('B and C' on Fig. 3). In addition, several NW-SE trending linear features akin to fracture zones are noticed to the east of the Comorin Ridge south of Sri Lanka.

\section{Discussions}

The seafloor spreading model studies reveal the presence of the Mesozoic magnetic anomaly sequence M11 to M0 trending in ENE-WSW to NE-SW direction south off Sri Lanka (Fig. 5). The six major (Fz1-Fz6) and some minor NNW-SSE to NW-SE trending fracture zones inferred from the offsets in the magnetic anomaly sequence corroborate well with those observed on the satellite gravity mosaic. The entire Mesozoic anomaly sequence (M11-M0) has evolved with variable half-spreading rates $(5.5-1.53 \mathrm{~cm} / \mathrm{yr})$, and the disposition of the anomalies by the fracture zones resulted in the formation of an arcuate shaped seafloor mosaic south of Sri Lanka. The oldest isochron (M11) occurs between 110 and $140 \mathrm{~km}$ from the Sri Lankan coast, while the Continent-Ocean Boundary (COB) inferred from the GEOSAT derived gravity mosaic occurs around $50 \mathrm{~km}$ from the coast. The region between the COB and the magnetic anomaly M11 may represent older crust (M12?). However, we cannot confidently identify this anomaly due to lack of adequate data.

The oldest magnetic anomaly of the Tertiary sequence, A34 is well constrained in the study area, and is offset by several N-S trending fracture zones. The offsets are in right lateral disposition $(55-85 \mathrm{~km})$ west of $85^{\circ} \mathrm{E}$ longitude. However, a large left lateral offset of about $900 \mathrm{~km}$ is inferred between 84 and $86^{\circ} 20^{\prime} \mathrm{E}$ longitudes. The width of the crust generated between the Mesozoic anomaly M0 and A34 (CMQZ) varies between $170 \mathrm{~km}$ towards the west $\left(80^{\circ} \mathrm{E}\right.$ longitude) and $500 \mathrm{~km}$ towards east $\left(85^{\circ} \mathrm{E}\right.$ longitude). A change in the direction of spreading during middle Cretaceous is evident from the orientations of the fracture zones associated with the Early (NNW-SSE to NW$\mathrm{SE})$ and Late Cretaceous (N-S) crusts. This change in the fracture zones 
azimuths reflects the first major plate reorganization during the middle Cretaceous. The magnetic anomalies and fracture zones identified in the present study are used as new constraints for the plate reconstruction models described below.

\subsection{Plate Reconstructions}

Using the results from the present study and published rotation poles, an attempt has been made to reconstruct the palaeopositions of Antarctica, India and Sri Lanka at various times keeping Antarctica fixed in its present day position (Table 1; Fig. 6).

160 Ma reconstruction:

Since Sri Lanka was placed close to India in several reconstructions at 160 Ma, (Powell et al., 1988; Scotese et al., 1988), we rotated Sri Lanka towards India using an Euler pole of $12^{\circ} \mathrm{N}$ latitude, $84.5^{\circ} \mathrm{E}$ longitude and angle of $-15^{\circ}$. India-Sri Lanka together was then rotated towards Antarctica using the pole parameters shown in table 1. A fairly good fit of the $2000 \mathrm{~m}$ isobath surrounding the two continents was obtained indicating that no breakup occurred between the continents prior to $160 \mathrm{Ma}$ (Fig. 6A).

\section{Ma reconstruction:}

The presence of Late Jurassic-Early Cretaceous sediments in the Gulf of Mannar and Mannar Basin (Baillie et al., 2002) indicates that the separation of Sri Lanka from India might have occurred prior to $134 \mathrm{Ma}$. Therefore, to generate a plate reconstruction model for $134 \mathrm{Ma}$ (M11), we rotated Sri Lanka initially using the Euler pole of $13^{\circ} \mathrm{N}$ latitude, $92^{\circ} \mathrm{E}$ longitude and angle of $-5^{\circ}$. India-Sri Lanka together was then rotated towards Antarctica using the pole parameters shown in table 1. A fairly good match (Fig. 6B) of the magnetic anomaly isochron M11 inferred in the offshore regions of India, Sri Lanka and East Antarctica was obtained. 


\section{Ma reconstruction:}

The reconstruction model for $121 \mathrm{Ma}(\mathrm{M} 0)$ was obtained by rotating India along with Sri Lanka with reference to Antarctica (Table 1). The model reveals that the fracture zones off India and Sri Lanka are complementary to those off East Antarctica implying that they represent flow lines describing the motion between these two plates. The isochron M0 inferred off Sri Lanka (present study) and east coast of India matches fairly well with that off East Antarctica (Fig. 6C).

\section{Ma reconstruction:}

For $84 \mathrm{Ma}$ (A34), we used the pole parameters of Powell et al., (1988) and Royer and Sandwell (1989) and generated the respective reconstruction models. The models so derived depicted a mismatch of the A34 isochron and the $86^{\circ} \mathrm{E}$ fracture zone. In order to minimize the gap in the mismatch, we have reworked on the above parameters based on the trend of the fracture zones inferred from the present study, and arrived at a new set of parameters for A34 chron (-9.0, -169.0, 65.0) which yielded a better fit (Fig. 6D). This reconstruction model also depicts a good match along the $86^{\circ} \mathrm{E}$ fracture zone. However, there still exists a slight mismatch of A34 isochron on the west of the $86^{\circ} \mathrm{E}$ fracture zone. This mismatch may be attributed to the frequent ridge jumps during the major plate reorganization within the middle Cretaceous period.

\subsection{Tectonic Implications}

Sri Lanka's position relative to India in the Gondwanaland reconstruction has never been well defined (Smith and Hallam, 1970; Crawford, 1974; Katz, 1978; Yoshida et al., 1992). Crawford (1974) repositioned Sri Lanka closer to India prior to breakup of Gondwanaland. The Precambrian formation of Sri Lanka was fitted against similar rocks of southeast India by closing up the Gulf of Mannar and Palk Strait and ignoring the intervening coastal Cretaceous and Tertiary deposits of southeast India and northwest Sri Lanka (Katz, 1978). The

Southwest group of rocks of Sri Lanka continues into the Kerala belt of 
southwest India while the Highland series of Sri Lanka continues into the Eastern Ghats belt of the eastern coast of India. Katz (1978) suggested an approximately $200 \mathrm{~km}$ late Mesozoic drift of Sri Lanka away from India with possible anti-clockwise rotation during early breakup of eastern Gondwanaland.

Curray (1984) opined that the first rifting between India, Sri Lanka and Antarctica occurred through the Cauvery-Palk Strait-Gulf of Mannar zone but this rift did not progress into the seafloor spreading stage. Instead, the break occurred between Sri Lanka and Antarctica, as a result the Cauvery-Palk StraitGulf of Mannar Basin became a failed rift or aulacogen dating from the Late Jurassic/Early Cretaceous. He also proposed that Sri Lanka acted as a midplate platelet moving slowly in a south-southeast direction relative to India.

The NE-SW trending feature of $\sim 190 \mathrm{~km}$ length on the gravity mosaic between India and Sri Lanka within the Mannar Basin (Fig. 3) appears to represent the failed rift system as surmised by Curray (1984). The two strong linear gravity lows, one parallel to Indian and the other sub-parallel to Sri Lankan coasts may either represent the transform ridges or the continentocean boundaries of India and Sri Lanka respectively.

Our study indicates that the oceanic crust south off Sri Lanka has evolved in the ENE-WSW to NE-SW direction with variable half-spreading rates during Early Cretaceous time. Similar order half-spreading rates were also estimated in the Bay of Bengal and Enderby Basin for the isochrons M11 through M0 suggesting similar plate kinematics prevailing during Early Cretaceous time. The Comorin Ridge trending in a NNW-SSE direction southwest of Sri Lanka is interpreted as a significant structural crustal boundary by Kahle et al., (1981). Since the trend of the Comorin Ridge is similar to that of the inferred fracture zones, it may have acted as a transform ridge during the early phase of opening of the Indian Ocean as opined by Powell et al., (1988).

The width of the middle Cretaceous crust between M0 and A34 isochrons is about $170 \mathrm{~km}$ in the vicinity of $80^{\circ} \mathrm{E}$ longitude, while it is about $500 \mathrm{~km}$ along $85^{\circ} \mathrm{E}$ longitude (Fig. 5). The large left lateral offset $(\sim 900 \mathrm{~km})$ of the A34 
isochron along $86^{\circ}$ longitude implies that the $86^{\circ} \mathrm{E}$ fracture zone acted as a major transform fault during the middle Cretaceous (Royer and Sandwell, 1989). Powell et al., (1988) predicted a change in spreading pattern around 96 Ma wherein the spreading ridge off the southern tip of India may have jumped back almost to the $\mathrm{COB}$ of India leaving any older ocean floor on the Antarctica plate. Tarduno et al., (1992) inferred several magnetic reversals during Albian within the middle Cretaceous, which perhaps implies the intensity of the thermal regime prevailing during that period. This thermal regime may have been more intense due to the proximity of the mantle plumes to the spreading axis, which resulted in the ridge jumps. Therefore, the probable occurrence of ridge jumps might be the reason for the presence of unequal width of the middle Cretaceous crust on the Indian plate.

The presence of the A34 magnetic anomaly in the south Crozet Basin, north of the Ob, Lena and Marion Dufresne seamounts indicates that the emplacement of these seamounts took place prior to 84 Ma time together with the adjacent oceanic crust. Anomalous volcanism near the spreading ridge axis (Diament and Goslin, 1986) might have occurred when major changes in configuration and direction of spreading took place during the middle Cretaceous resulting in northward jumps of the spreading centers. This perhaps explains the mismatch in the $A 34$ isochron west of the $86^{\circ} \mathrm{E}$ fracture zone in the A34 plate reconstruction model (Fig. 6D).

\section{Conclusions}

Study of magnetic data and the synthetic seafloor spreading model suggest the presence of the Mesozoic anomaly sequence M11 through M0 (134-121 $\mathrm{Ma})$, and the Mesozoic crust spread in an ENE-WSW to NE-SW direction south of Sri Lanka. The oldest magnetic anomaly isochron M11 occurs between 110 and $140 \mathrm{~km}$ away from the Sri Lankan coast confirming that the breakup of eastern Gondwanaland took place prior to the formation of M11 isochron.

The seafloor created during Early Cretaceous is estimated to have evolved with variable half-spreading rates ranging between 5.5 and $1.53 \mathrm{~cm} / \mathrm{yr}$. The 
NNW-SSE and NW-SE trends of the fracture zones inferred from the disposition of the magnetic anomalies are constrained by the satellite gravity data. The middle Cretaceous crust is estimated to have evolved with a slower spreading rate. The boundary between the middle and late Cretaceous crusts represented by magnetic anomaly A34 ( 84Ma) has been redefined between $3^{\circ} \mathrm{S}$ and $2^{\circ} \mathrm{N}$ latitudes. Orientation of the fracture zones of the early Cretaceous crust ( NNW-SSE) is different from that of the Tertiary crust (N-S) indicating a change in the spreading direction.

The Cretaceous Magnetic Quiet Zone (CMQZ, 121-84 Ma) crust between the isochrons $\mathrm{MO}$ and $\mathrm{A} 34$ is of unequal width. West of $80^{\circ} \mathrm{E}$ longitude, the width is about $170 \mathrm{~km}$, while towards east between 83 and $85^{\circ} \mathrm{E}$ longitudes, the width is seen gradually increasing to $500 \mathrm{~km}$. This inequality in width may be attributed to the occurrence of ridge jumps within the middle Cretaceous time.

The newly identified Mesozoic magnetic anomalies M11 through M0 and fracture zones served as new constraints in revalidation of the earlier proposed plate reconstruction models for $160 \mathrm{Ma}$ (Fit), $134 \mathrm{Ma}$ (M11), $121 \mathrm{Ma}$ (M0) and $84 \mathrm{Ma}$ (A34). The mismatch in the disposition of the A34 isochron can be attributed to the likely occurrence of northward ridge jumps and/or emplacement of the $\mathrm{Ob}$, Lena and Marion Dufresne seamounts at the spreading ridge axis during the major plate reorganization in the middle Cretaceous.

\section{Acknowledgements}

The authors would like to thank Director, NIO for granting necessary permission. Dr. J-Y. Royer provided the required insight for computing the plate reconstruction models and Dr. J. Dyment discussed the aspect of tectonics of the Gulf of Mannar. The constructive comments of Dr. R. L. Larson helped in improving the earlier version of the manuscript considerably. The authors would like to thank profoundly Drs. J. R. Curray and E. Lodolo for carefully reviewing this manuscript and offering valuable comments. GMT software (Wessel and Smith, 1998) was used to generate the maps in this paper. This is NIO Contribution: 4126 
Table 1: Finite rotations of relative motion of India and Sri Lanka with respect to Antarctica in its present day position

\begin{tabular}{lllll}
\hline Chron & $\begin{array}{l}\text { Latitude } \\
{\left[{ }^{\circ} \mathrm{N}\right]}\end{array}$ & $\begin{array}{l}\text { Longitude } \\
{\left[+{ }^{\circ} \mathrm{E}\right]}\end{array}$ & $\begin{array}{l}\text { Rotation } \\
\text { Angle }\left[{ }^{\circ}\right]\end{array}$ & Reference \\
\hline M29 & 4.22 & -162.86 & 92.45 & Powell et al., 1988 \\
M11 & -1.5 & -171.6 & 84.95 & Ramana et al., 2001 \\
M0 & -5.00 & -166.30 & 76.58 & Ramana et al., 2001 \\
A34 & -7.3 & -170.7 & 64.78 & Powell et al., 1988 \\
A34 & -7.8 & -169.1 & 65.10 & Royer and Sandwell, 1989 \\
A34 & -9.00 & -169.00 & 65.00 & Present study \\
\hline
\end{tabular}




\section{References}

Baillie, P. W., Shaw, R. D., Liyanaarachchi, D. T. P, Jayaratne. M. G., 2002. A new Mesozoic Sedimentary Basin, offshore Sri Lanka, EAGE, 64 ${ }^{\text {th }}$ Conference and Exhibition, Italy.

Bergh, H. W., 1977. Mesozoic seafloor off Dronning Maud Land, Antarctica, Nature 269, 686-687.

Bull, J. M., Martinod, J., Davy, P., 1992. Buckling of the oceanic lithosphere from geophysical data and experiments, Tectonics 11, 537-548.

Crawford, A. R., 1974. Indo-Antarctica, Gondwanaland, and the distortion of a granulite belt, Tectonophysics 22, 141-157.

Curray, J. R., 1984. Sri Lanka: is it a mid-plate platelet? J. NARA 31, 30-50.

Curray, J. R., 1994. Sediment volume and mass beneath the Bay of Bengal, Earth Planet. Sci. Lett. 125, 371-383.

Curray, J. R., Emmel, F. J., Moore, D. G., Raitt, R. W., 1982. Structure, tectonics and geological history of the Northeastern Indian Ocean, in: A. E. Nairn, F. G. Stehli (Eds.), The Ocean Basins and Margins, 6, Plenum, New York, pp.399-450.

Curray, J. R., Munasinghe, T., 1991. Origin of the Rajmahal Traps and the $85^{\circ} \mathrm{E}$ Ridge: Preliminary reconstructions of the trace of the Crozet hotspot, Geology 19, 1237-1240.

Diament, M., Goslin, J., 1986. Emplacement of the Marion Dufresne, Lena and $\mathrm{Ob}$ seamounts (South Indian Ocean) from a study of isostasy, Tectonophysics 121, 253-262.

Gradstein, F. M., Agterberg, F. P., Ogg, J. G., Hardenbol, J., van Veen, P., Thierry, J., Huang, Z., 1994. A Mesozoic time scale, J. Geophys. Res. 99, 24051-24074.

Heezen, B. C., Tharp, M., 1964. Physiographic diagram of the Indian Ocean, map, Geol. Soc. Am., Boulder, Colorado.

Johnson, B. D., Powell, C. M., Veevers, J. J., 1976. Spreading history of the Eastern Indian Ocean and Greater India's Flight from Antarctica and Australia, Geol. Soc. Am. Bull. 87, 1560-1566. 
Kahle, H. G., Naini, B. R., Talwani, M., Eldholm, O., 1981. Marine geophysical study of the Comorin Ridge, North Central Indian Basin, J. Geophys. Res. 86 (B5), 3807-3814.

Katz, M. B., 1978. Sri Lanka in Gondwanaland and the evolution of the Indian Ocean, Geological Magazine 115 (4), 237-244.

Krishna, K. S., Ramana, M. V., Gopala Rao, D., Murthy, K.S.R., Malleswara Rao, M. M., Subrahmanyam, V., Sarma, K.V.L.N.S., 1998. Periodic deformation of oceanic crust in the Central Indian Ocean, J. Geophys. Res. 103 (B8), 17859-17875.

Larson, R. L., 1977. Early Cretaceous breakup of Gondwanaland off Western Australia, Geology 5, 57-60.

Markl, R. G., 1974. Evidence of breakup of Eastern Gondwanaland by Early Cretaceous, Nature 251, 196-200.

McKenzie, D., Sclater, J. G. 1971. The evolution of the Indian Ocean since the late Cretaceous, Geophys. J. R. Astr. Soc. 25, 437-528.

Norton, I. O., Sclater, J. G. 1979. A model for the evolution of the Indian Ocean and the break up of Gondwanaland, J. Geophys. Res. 84, 6803-6830.

Powell, C. M., Roots, S. R., Veevers, J. J., 1988. Pre-breakup continental extension in East Gondwanaland and the early opening of the eastern Indian Ocean, Tectonophysics 155, 261-283.

Ramana, M. V., Nair, R. R., Sarma, K. V. L. N. S., Ramprasad, T. Krishna, K. S., Subrahmanyam, V., D'Cruz, M., Subrahmanyam, C., Paul, J., Subrahmanyam, A. S., Chandrasekhar, D. V., 1994. Mesozoic anomalies in the Bay of Bengal, Earth Planet. Sci. Lett. 121, 469-475.

Ramana, M. V., Ramprasad, T., Desa, M., 2001. Seafloor spreading magnetic anomalies in the Enderby basin, East Antarctica, Earth Planet. Sci. Lett. 191, 241-255.

Ramana, M. V., Subrahmanyam, V., Sarma, K.V.L.N.S, Desa, M., Malleswara Rao, M. M., Subrahmanyam, C., 1997a. Record of the Cretaceous Magnetic Quiet Zone: A precursor to the understanding of the evolutionary history of the Bay of Bengal, Curr. Sci. 72, 669-673. 
Ramana, M. V., Subrahmanyam, V., Chaubey, A. K., Ramprasad, T., Sarma, K. V. L. N. S., Krishna, K. S., Desa, M., Murty, G. P. S., 1997b. Structure and origin of the $85^{\circ} \mathrm{E}$ Ridge, J. Geophys. Res., 102,17995-18012.

Robb, M. S., Taylor, B., Goodliffe, A. M., 2005. Re-examination of the magnetic lineations of the Gascoyne and Cuvier Abyssal Plains, off NW Australia, Geophys. J. Int., 163, 42-55.

Rohr, K., Twigt, W., 1980. Mesozoic complementary crust in the North Atlantic, Nature 283, 758-761.

Royer, J.-Y., Sandwell, D. T., 1989. Evolution of the eastern Indian Ocean since the Late Cretaceous: Constraints from GEOSAT altimetry, J. Geophys. Res. 94, 13755-13782.

Royer, J. Y., Sclater, J. G., Sandwell, D. T., 1989. A preliminary tectonic fabric chart of the Indian Ocean, in: Brune, J. N., (Eds.), Proc. Ind. Acad. Sci., Earth Planet. Sci. 98, 7-24.

Royer, J-Y., Peirce, J. W., Weissel, J. K., 1991. Tectonic constraints on the hotspot formation of Ninetyeast Ridge, in: Weissel, J. K et al., (Eds.), Proc. ODP, Sci. Res., 121, pp. 763-776.

Sandwell, D. T., Smith, W. H. F., 1997. Marine gravity anomaly from GEOSAT and ERS-1 satellite altimetry, J. Geophys. Res. 102, 10039-10054.

Schlich, R., 1982. The Indian Ocean: aseismic ridges, spreading centers and ocean basins, in: A. E. Nairn, F. G. Stehli (Eds.), The Ocean Basins and Margins, 6, Plenum, New York, pp. 51-147.

Sclater, J. G., Fisher, R. L., 1974. Evolution of the east Central Indian Ocean with emphasis on the tectonic setting of the Ninetyeast Ridge, Geol. Soc. Amer. Bull. 85, 683-702.

Scotese, C. R., Gahagan, L. M., Larson, R. L. 1988. Plate tectonic reconstructions of the Cretaceous and Cenozoic ocean basins, Tectonophysics 155, 27-48.

Shemenda, A. I., 1992. Horizontal lithosphere compression and subduction: Constraints provided by physical modeling, J. Geophys. Res. 97, 1109711116. 
Simpson, E. S. W., Sclater, J. G., Parsons, B., Norton, I. O., Meinke, L., 1979. Mesozoic magnetic lineations in the Mozambique Basin, Earth Planet. Sci. Lett. 43, 260-264.

Smith, A. G., Hallam, A., 1970. The fit of the southern continents, Nature 225, 139-144.

Stein, C. A., Cloetingh, S., Wortel, R., 1990. Kinematics and mechanics of the Indian Ocean diffuse plate boundary zone, in: J. R. Cochran, D. A. V. Stow et al., (Eds.), Proc. ODP, Sci. Res. 116, College Station, TX, pp. 261-277.

Tarduno, J. H., Lowrie, W., Sliter, W. V., Brallower, T. J., Heller, F., 1992. Reversed polarity characteristic magnetizations in the Albian Coutessa section, Umbrian Apenniner, Italy; Implications for the existence of a midCretaceous mixed polarity interval, J. Geophys. Res. 97, 241-271.

Wessel, P., Smith, W. H. F., 1998. New improved version of Generic Mapping Tools released, EOS Trans. AGU 79, 579.

Yoshida, M., Funaki, M., Vitanage, P. W., 1992. Proterozoic to Mesozoic east Gondwanaland: the juxtaposition of India, Sri Lanka and Antarctica, Tectonics 11, 381-391. 


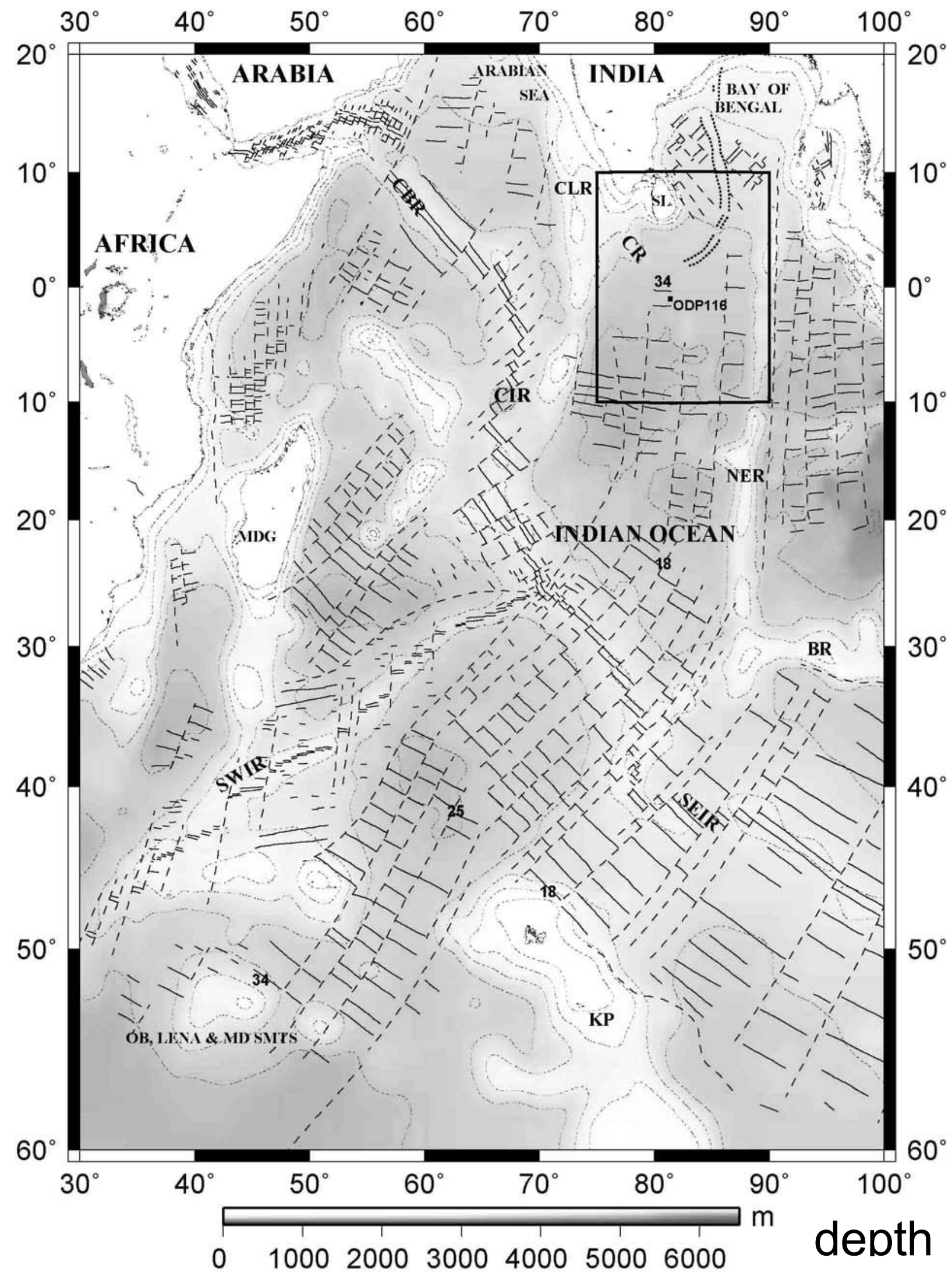

Fig. 1. Gray scale shaded map depicting the general topography of the Indian Ocean. Bathymetry contour interval is $1000 \mathrm{~m}$. A depth scale is shown at the bottom. The box represents the study area. Fracture zones (dashed lines) and magnetic lineations (solid lines, a few of which are labeled with magnetic anomaly numbers) are from earlier works (Royer et al., 1989; Ramana et al., 2001). Thick dashed line pair represents the boundary of the subsurface $85^{\circ} \mathrm{E}$ Ridge. NER - Ninetyeast Ridge; CLR -Chagos-Laccadive Ridge; SL - Sri Lanka; MD - Marion Dufresne; BR - Broken Ridge; KP - Kerguelen Plateau; MDG - Madagascar; CRComorin Ridge; CBR - Carlsberg Ridge; CIR - Central Indian Ridge; SWIR - Southwest Indian Ridge; SEIR Southeast Indian Ridge. 


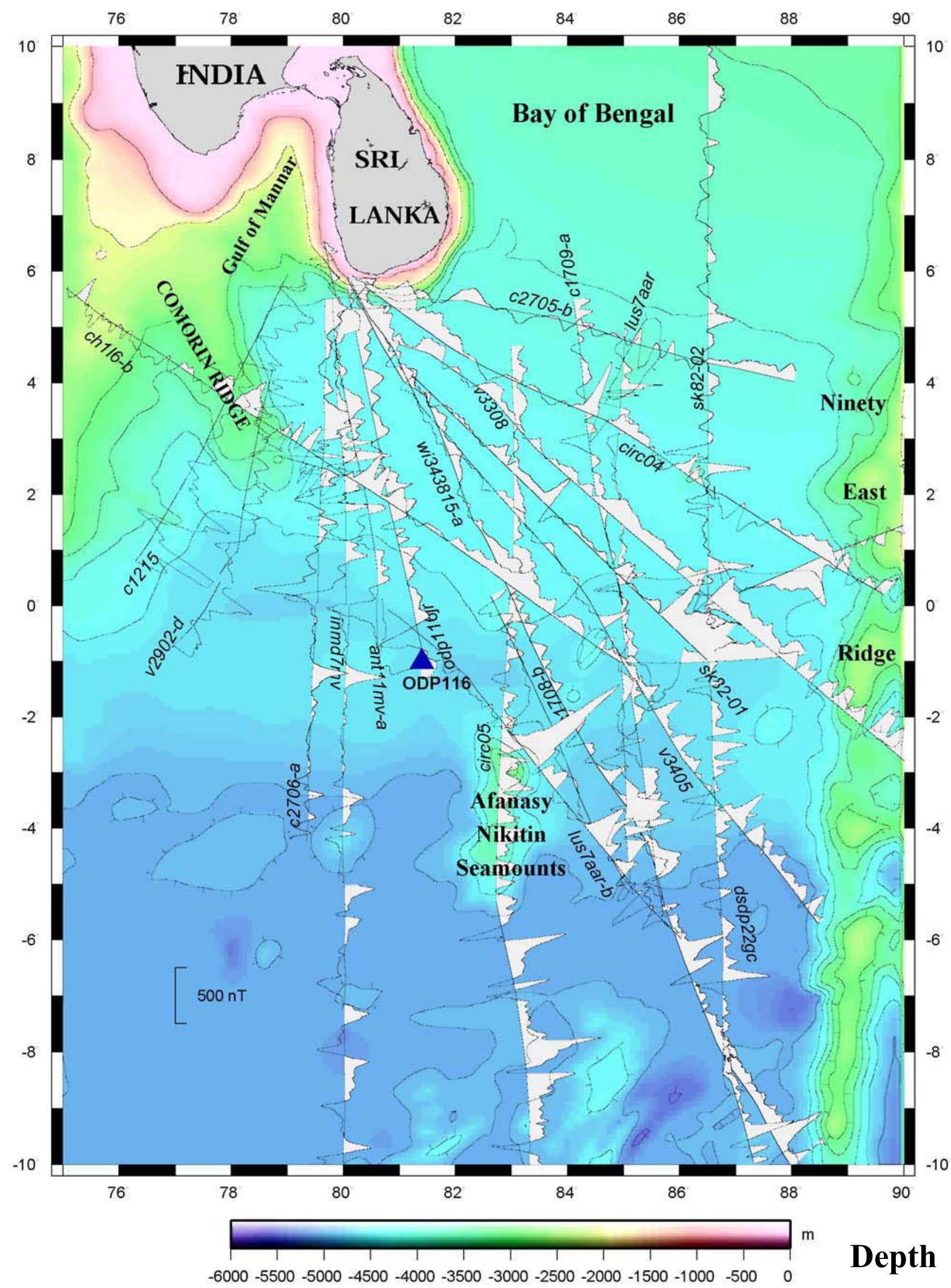

Fig. 2. Detailed bathymetry of the study area along with the residual magnetic anomalies plotted perpendicular to the cruise tracks. The Comorin Ridge, Ninetyeast Ridge, Afanasy Nikitin seamounts and other isolated highs are indicated. 


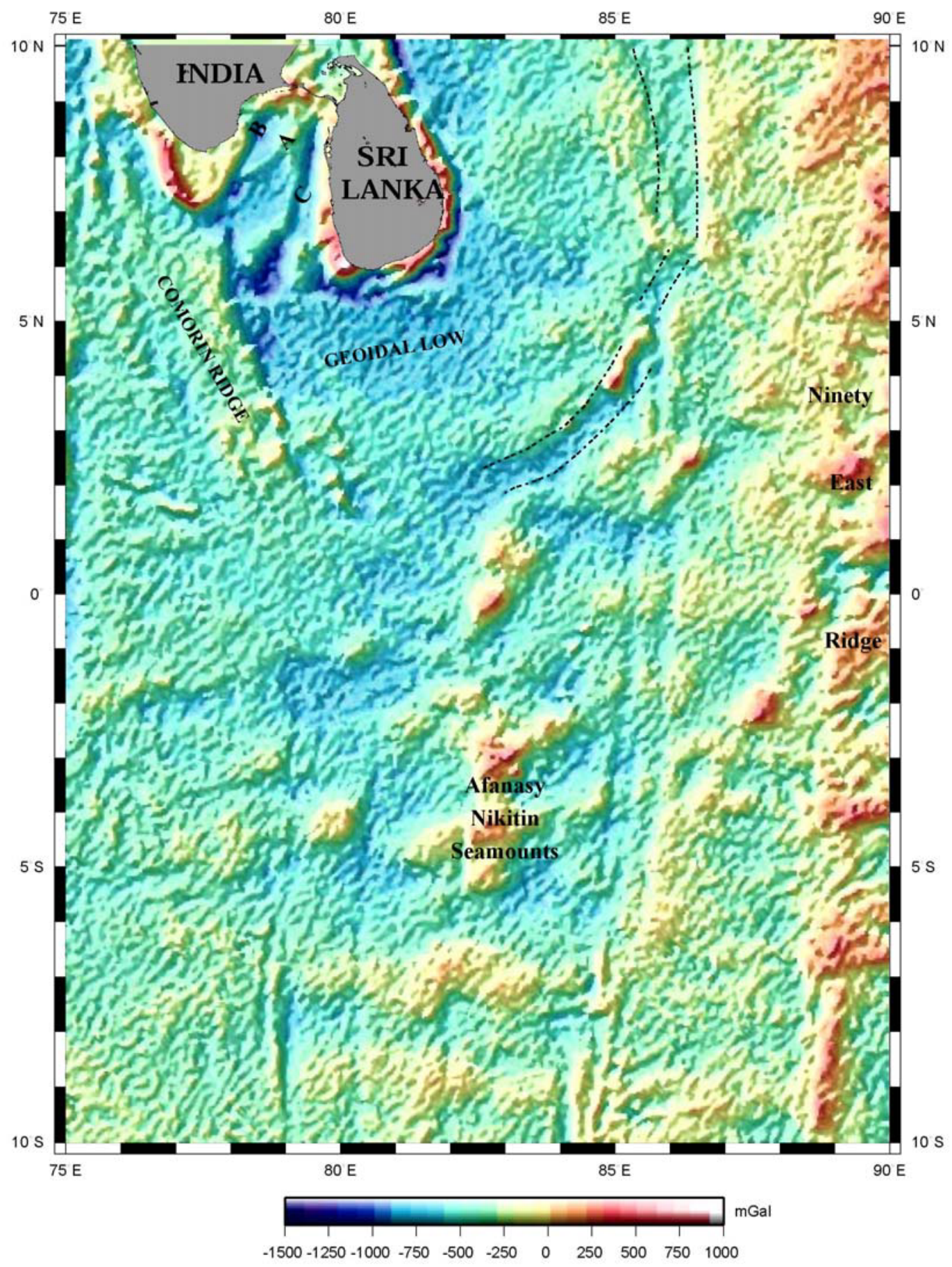

Fig. 3. GEOSAT/ERS-1 derived free-air gravity anomaly mosaic (after Sandwell and Smith, 1997) of the study area. The map depicts several N-S trending linear features akin to fracture zones in the south of the study area, whereas south of Sri Lanka, NNW-SSE to NW-SE trending features are conspicuous. The other distinct features are: i) gravity minimum south of Sri Lanka (geoidal low); ii) NNW-SSE trending gravity high corresponding to the Comorin Ridge, southwest of Sri Lanka; iii) a NE-SW trending linear feature in the Gulf of Mannar ('A'); iv) two approximately NNE-SSW trending linear gravity lows, one off southern tip of India ('B'), and the other sub-parallel to the west coast of Sri Lanka ('C'); v) an arcuate shaped gravity low corresponding to the subsurface $85^{\circ} \mathrm{E}$ Ridge represented by paired dashed lines; and vi) alternate bands of gravity lows and highs caused by deformation. Linear positive gravity field in the extreme right of the study area corresponds to the Ninetyeast Ridge. The Afanasy Nikitin seamounts chain is characterized with positive gravity field aligned in a N-S direction between 82 and $83^{\circ} 30^{\prime} \mathrm{E}$ longitudes. 


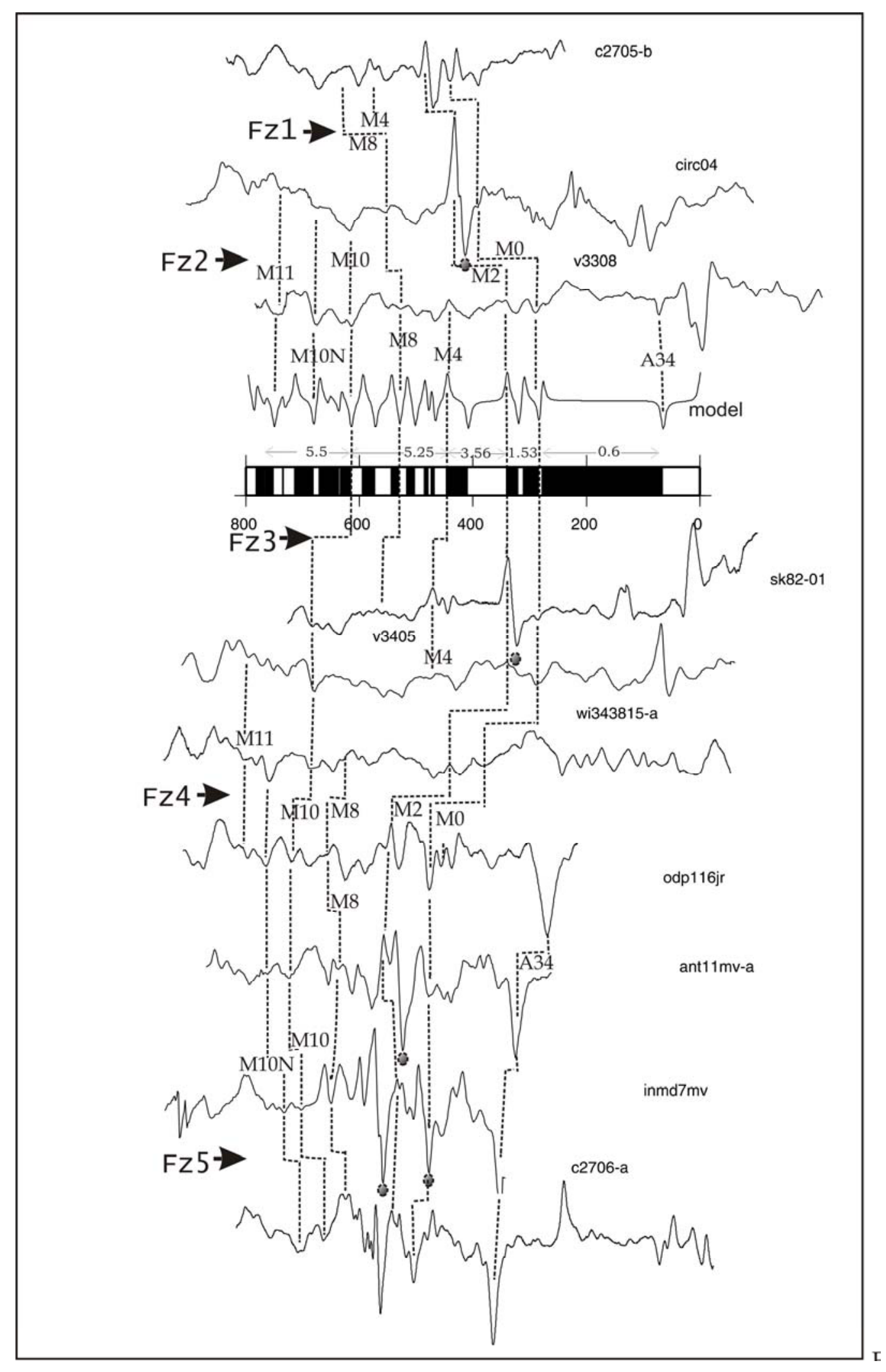

Fig. 4. Synthetic seafloor spreading model generated along the V3308 profile using the magnetic polarity time scale of Gradstein et al., (1994) to constrain the anomalies M11 through M0 from known anomaly A34. This model was computed for the oceanic crust generated at paleolatitude of $60^{\circ} \mathrm{S}$ with a thickness of the magnetized layer of $500 \mathrm{~m}$ and a magnetic susceptibility of $0.015 \mathrm{cgs}$ units. The magnetic anomalies correlate well with the synthetic model. Fz indicates fracture zone. Bathymetric high along a profile is indicated with a dark circle. 


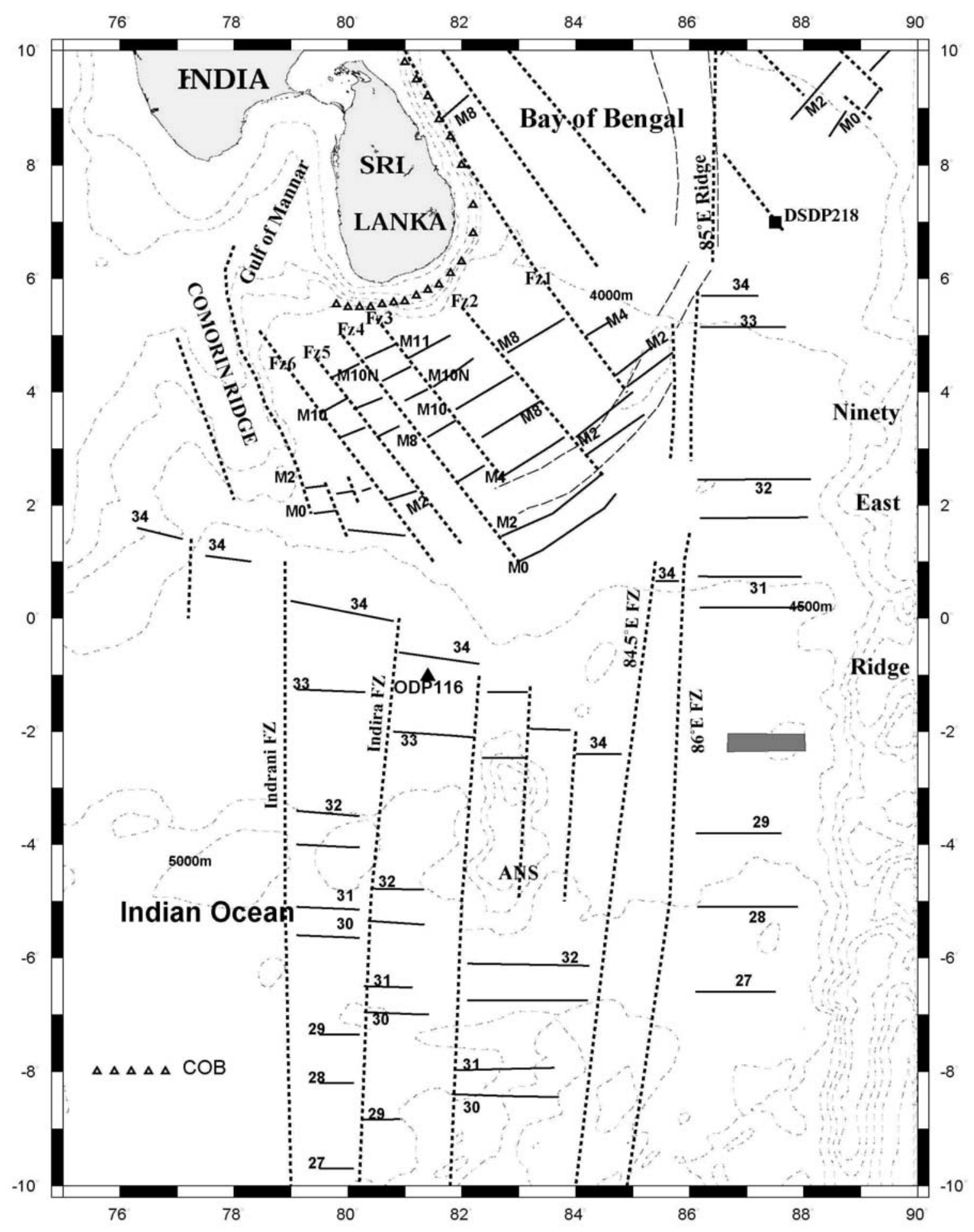

Fig. 5. Tectonic map depicting the newly interpreted magnetic anomaly lineations and fracture zones in the study area. The trends of these fracture zones are constrained by the GEOSAT/ERS-1 gravity mosaic. The anomaly identifications are based on the synthetic model shown in Fig. 4. Magnetic anomalies identified by earlier workers (Royer et al., 1991; Ramana et al., 2001) are also shown. Gray shaded box at the right indicates a fossil ridge (Royer et al., 1991). The Continent-Ocean Boundary is marked by triangles. The southern extent of the $85^{\circ} \mathrm{E}$ Ridge is also shown. 


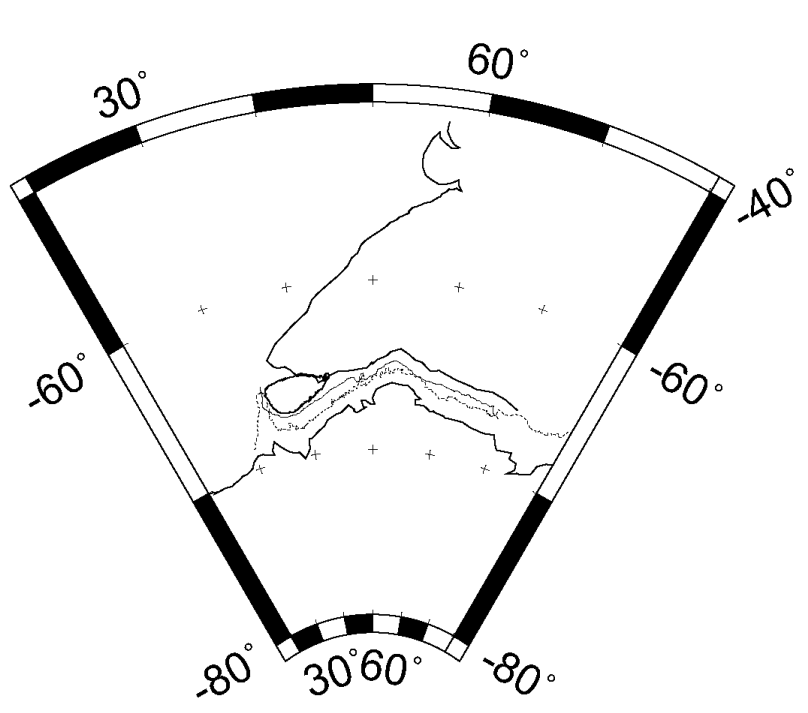

(A) $160 \mathrm{Ma}$ (Fit)

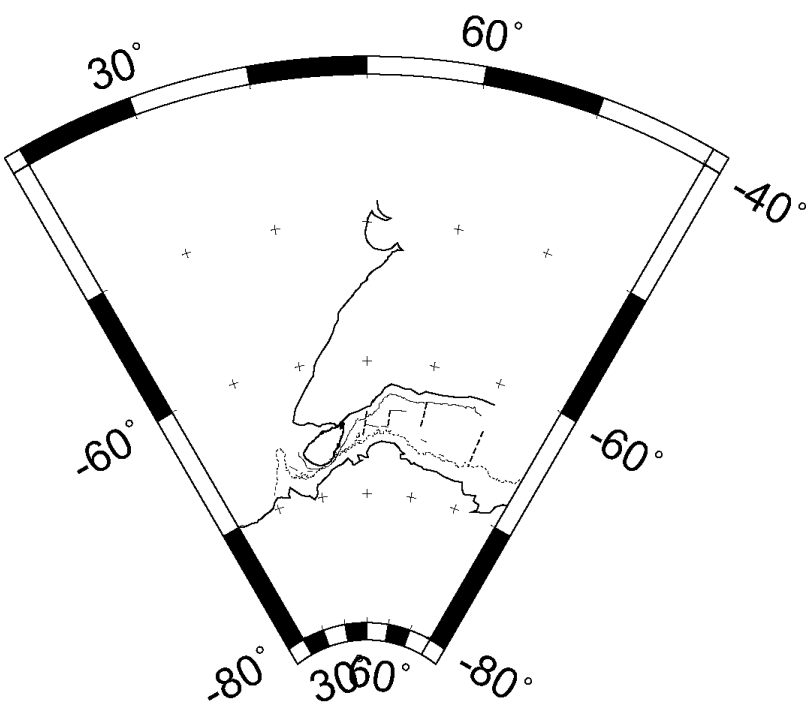

(B) $134 \mathrm{Ma}(\mathrm{M} 11)$

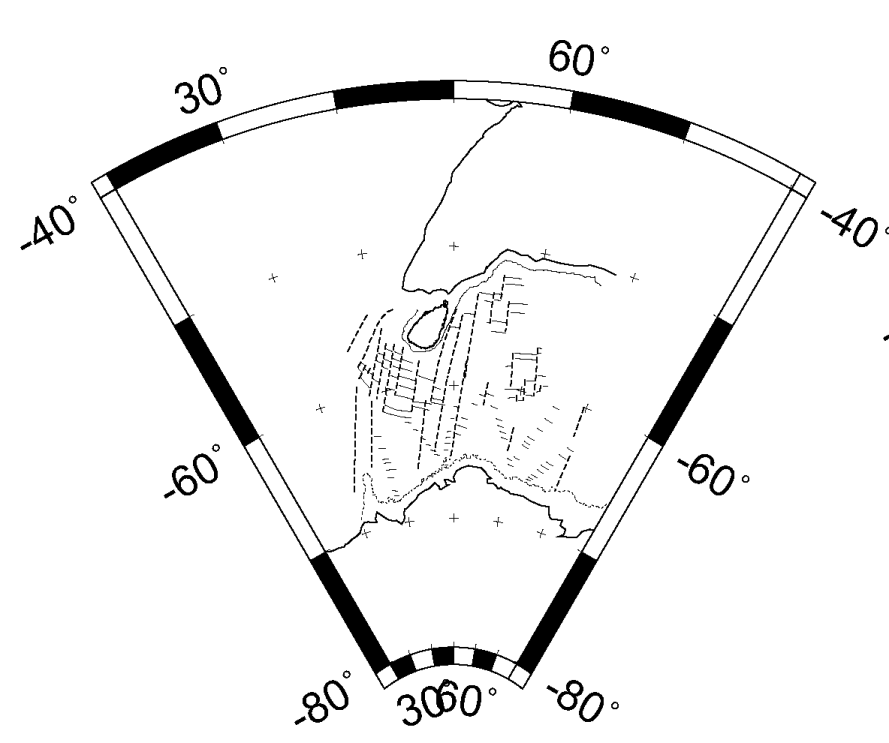

(C) $121 \mathrm{Ma} \mathrm{(M0)}$

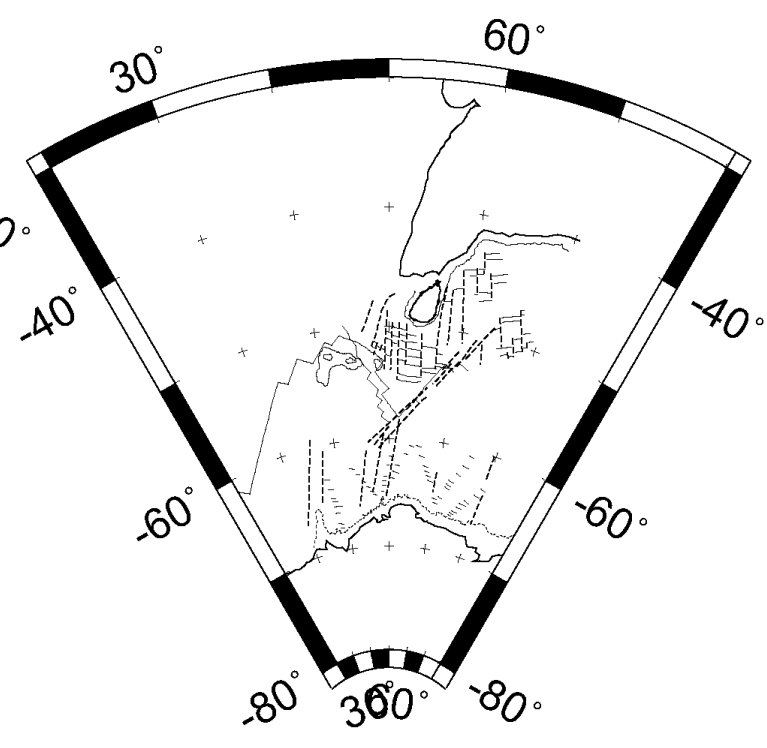

(D) $84 \mathrm{Ma}(\mathrm{A} 34)$

Fig. 6. Plate reconstruction models depicting palaeo positions of the magnetic anomaly lineations and fracture zones inferred from the present study. All the reconstructions are made using the finite rotation poles (Powell et al., 1988; Ramana et al., 2001) as indicated in Table 1. The reconstructions correspond to the initial fit (160 Ma), M11 (134 Ma), M0 (121 Ma) and A34 (84 Ma) keeping Antarctica fixed in its present-day position. 